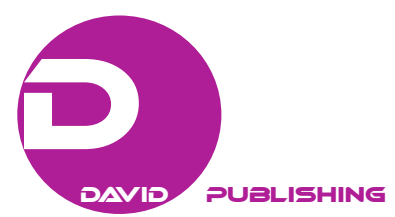

\title{
Status and the Future of Organic Farming in the Republic of Macedonia and the Mediterranean Countries
}

\author{
Ljupcho Mihajlov, Vasko Zlatkovski, Natalija Markova Ruzdik \\ Goce Delchev University, Shtip, Republic of Macedonia
}

\begin{abstract}
In order to create or design a development, it is necessary to have a look backwards. To identify and understand the resources based on the possessed knowledge, steps for development are proposed. But, no less important is to understand the surrounding, what others are doing/planning, as it will save precious time in inventing something which is maybe already implemented elsewhere. Based on that assumption, this paper deals with the analysis of the current status of the organic farming (O.F.) in Macedonia and the Mediterranean countries, as they are closest to the soil and climate conditions that exist in Macedonia as well. This paper will try to give answer to the question "how to maintain the present level of development and to set parameters which should be used in order to reach further development". The analysis process was implemented by using SWOT (strength, weakness, opportunity, and threats) analysis for Macedonia and the Mediterranean countries. The analysis result indicates that there are numerous common factors, resources, structures, and gaps in the organic sector. This paper's goal is to present a list of strategic goals and instruments for development of O.F. in Macedonia and Mediterranean countries. The data related to the facts and visions are referred to the Republic of Macedonia, but relevant data on EU countries, candidate-countries, and south Mediterranean countries are presented as well. The conclusions are with special accent to the new possibilities for development of O.F. in the near future, especially through applicative scientific research activities.
\end{abstract}

Keywords: organic farming (O.F.), analysis, development, data, visions, improvement, efficiency

\section{Introduction}

As compared to the conventional, organic farming (O.F.) is characterized by several different specifics. Holistic and environmental approach gives this kind of farming unique production dimension, given the influence of ambient conditions which tends to differ even on micro-regional level. In the first decades of the 20th century, scientifically formed concepts were brought into the traditional instinctive approach to nature. Change of lifestyle laid the foundations for changes in nutrition, hygiene, and physical culture. It was based not only on an attempt to adapt life to nature, but also on scientific knowledge (Sharapatka \& Urban, 2009).

Ljupcho Mihajlov, Ph.D., Department of Plant Production, Faculty of Agriculture, Goce Delchev University, Shtip, Republic of Macedonia.

Vasko Zlatkovski, M.Sc., Department of Plant and Environment Protection, Faculty of Agriculture, Goce Delchev University Shtip, Republic of Macedonia.

Natalija Markova Ruzdik, M.Sc., Department of Plant Production, Faculty of Agriculture, Goce Delchev University Shtip, Republic of Macedonia.

Correspondence concerning this article should be addressed to Ljupcho Mihajlov, 10 A, Krste Misirkov str., P.O. Box 201, 2000 Shtip, Republic of Macedonia. E-mail: ljupco.mihajlov@ugd.edu.mk. 
Organic Trade Association (2010) revealed that U.S. sales of organic products continued to grow during 2009 , whereas organic food and non-food product sales in that year grew by $5.3 \%$, despite the distressed state of the economy (Reine, Pugliese, \& Al-Bitar, 2010). The organic production methods attracted also the attention of local governments and economic operators and found space in discussion platforms and official strategies papers (Al-Bitar, Bteich, \& Pugliese, 2010). The facts and figures about organic agriculture statistics in this area have almost doubled between 2001 and 2007 (Al-Bitar \& Pugliese, 2008) and continued to increase in terms of organic agricultural land. In 2008, with more than 143 thousand operators, organic agriculture in the Mediterranean covered an area of about five million ha of which around 1.3 million ha of wild collection and forests, mainly concentrated in Eastern Adriatic and some South-Eastern countries (Al-Bitar et al., 2010). Many non-EU Mediterranean countries already have a national law (Tunisia, Turkey, Serbia, Croatia, Macedonia, and Montenegro) and a well-developed export market (Morocco, Tunisia, Turkey, and Serbia), while local markets are still emergent. After close study of the SWOT (strength, weakness, opportunity, and threats) analysis performed in Macedonia and by the Mediterranean countries, it is clear that there are numerous common factors, resources, structures, and gaps in the organic sector. The research goal in this paper is to present in a sublimated referent document in a form of listed strategic goals and instruments for development in Macedonia and Mediterranean countries. Much indicates that the highly applied research has had a very important part to play in the development of the sector. But rarely have research programs been analyzed and evaluated on their effect on a sector of society and this is generally thought to be quite difficult, among other things, because it can be difficult to distinguish the contribution from research from those of other development forces.

\section{Materials and Methods}

The data related to the conditions in the Republic of Macedonia are based upon own research activities, as well as of the Ministry of Agriculture, Forestry and Water Economy of the Republic of Macedonia (Retrieved from http://www.mzsv.gov.mk/organsko_zemjodelsko_proizvodstvo2013.pdf), statistical publications which are in majority of the cases published in the National Plan of Organic Farming 2013-2020. The National Plan for Organic Production 2013-2020 was adopted by the Government of the Republic of Macedonia on the 178th session held on December 30, 2013. The part of the document which is related to the situation in Mediterranean countries is performed through processing data published by the Mediterranean Agronomic Institute of

Bari-Italy. Relevant facts and data from scientific research activities and possibilities of their applicative purpose, which are presented in this paper, were taken from the publication of the International Centre for Research in Organic Food Systems (2011). Using comparative and analytical methods, own and other researchers' interview results, strategic goals for O.F. are emphasized for Macedonia and Mediterranean countries.

\section{Results and Discussions}

In 2007, the Government of the Republic of Macedonia has adopted the National Strategy for Agriculture and Rural Development in which a strategic goal is defined for development of agriculture and the rural sector for the period from 2007 to 2013, and which states to strengthen the agriculture in order to become competitive on integrated regional markets of EU and SE Europe through:

- improving efficiency of agricultural production, processing, and marketing;

- establishing relevant public and private institutions; 
- improving farm efficiency;

- ensuring consumers who have access to safe and healthy food;

- optimizing the use of limited resources, such as soil, water, and forest;

- establishing vital rural communities through sustainable rural development.

The National Plan for Organic Production 2013-2020 relates to the following parts of organic production: (1) production (plant production and animal production); (2) processing; (3) trade; (4) research, education, and science; (5) policy, legislation, and control; and (6) input materials. Based on performed SWOT analysis on different subsectors in agriculture, analysis of the conditions in O.F. is performed and strategic goals are set, as well as specific policy goals and activities that are to be implemented during this time frame. In the action plan for O.F., several activities are set, such as: area of intervention, activities, approach, and time frame for task completion. The development of the organic sector in Macedonia till 2011 records steady growth as presented in Figure 1 (Retrieved from http://www.mzsv.gov.mk/files/National\%20Plan\%20for\%20Organic\% 20Production_2013\%20-\%202020.pdf).

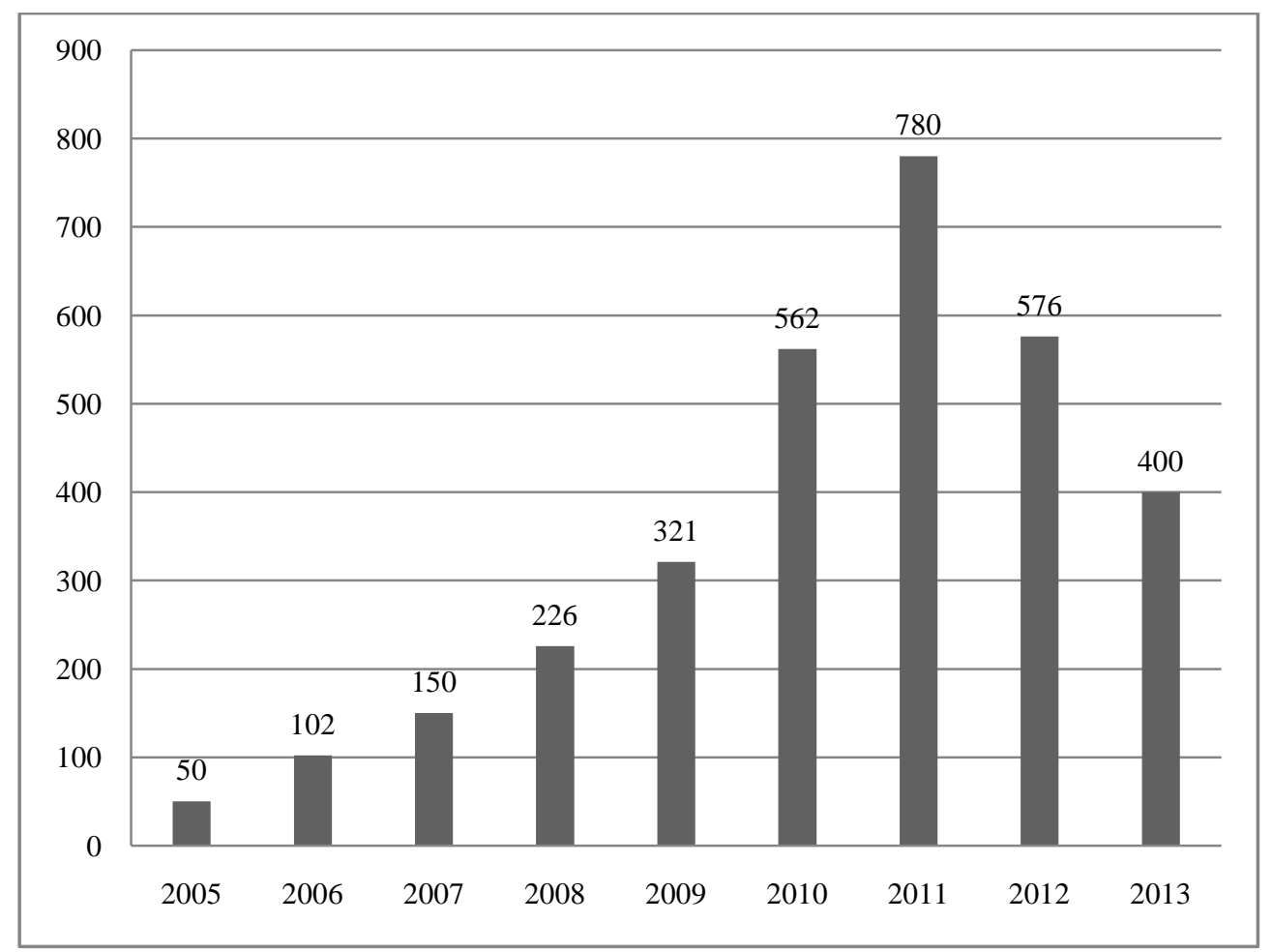

Figure 1. Number of operators 2005-2013 in Republic of Macedonia.

Driven by the increased number of operators and processing facilities in the past few years, the governmental support increased the level of subsidy in this sector as presented in Figure 2 (Retrieved from http://www.mzsv.gov.mk/files/National\%20Plan\%20for\%20Organic\%20Production_2013\%20-\%202020.pdf).

Similar is the situation in the remaining Mediterranean countries, too. More and more subjects are joining thus contributing to the expansion of production facilities. In the past few years, a growth trend is recorded, since many operators are joining and processing facilities are expanding as presented in Tables 1 and 2 (Organic World, 2015; Al-Bitar, 2008). 


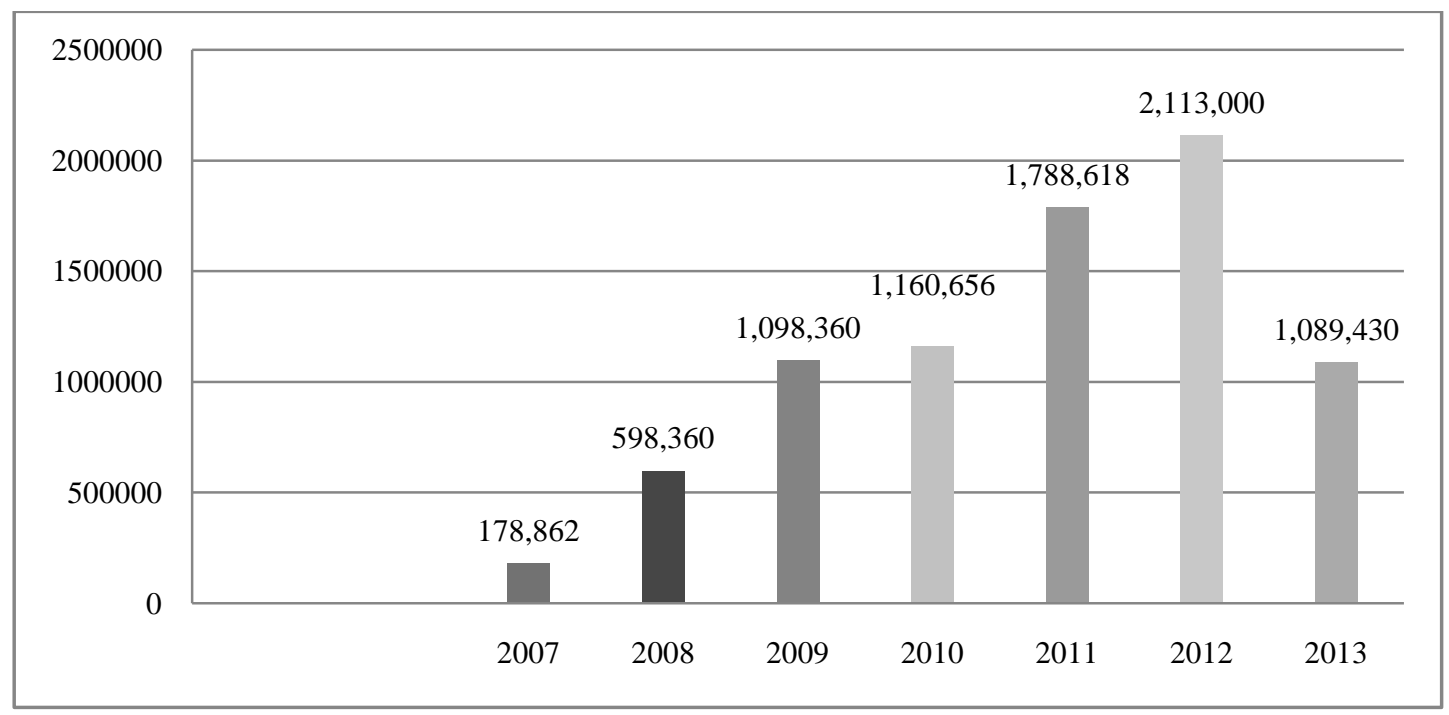

Figure 2. Level of financial support in organic farming 2007-2013 (in €).

Table 1

Certified Area Under Organic in the Mediterranean Basin

\begin{tabular}{|c|c|c|c|c|c|c|c|c|c|}
\hline \multirow[b]{3}{*}{ Country } & \multicolumn{9}{|c|}{ Indicator-Year } \\
\hline & \multicolumn{9}{|c|}{ Area (ha) } \\
\hline & 2005 & 2006 & 2007 & 2008 & 2009 & 2010 & 2011 & 2012 & 2013 \\
\hline Albania & 1,170 & 142 & 183 & 331 & 271 & 284 & 360 & 425 & 662 \\
\hline Algeria & 887 & 1,550 & 1,550 & 1,042 & 622 & 623 & 692 & 700 & 700 \\
\hline $\begin{array}{l}\text { Bosnia and } \\
\text { Herzegovina }\end{array}$ & 416 & 726 & 691 & 691 & 580 & 580 & 343 & 343 & 292 \\
\hline Croatia & 3,124 & 6,145 & 7,561 & 10,010 & 14,194 & 23,352 & 24,820 & 29,342 & 40,641 \\
\hline Cyprus & 1,698 & 1,979 & 2,322 & 2,322 & 3,575 & 3,575 & 3,502 & 3,124 & 3,923 \\
\hline Egypt & 24,548 & 14,165 & 19,206 & 40,000 & 56,000 & 82,167 & 82,167 & 85,801 & 85,801 \\
\hline France & 550,488 & 552,824 & 557,133 & 583,799 & 677,513 & 845,442 & 727,227 & 954,099 & $1,053,829$ \\
\hline Greece & 288,737 & 302,264 & 281,042 & 317,824 & 326,252 & 309,823 & 195,273 & 454,154 & 383,606 \\
\hline Israel & 4,557 & 4,058 & 5,693 & 6,400 & 6,969 & 8,794 & 7,095 & 6,187 & 7,471 \\
\hline Italy & $1,069,462$ & $1,148,162$ & $1,150,253$ & $1,002,414$ & $1,106,684$ & $1,113,742$ & $1,000,744$ & $1,071,799$ & $1,317,177$ \\
\hline Jordan & 10 & 1,024 & 1,047 & 1,053 & 1,053 & 1,469 & 2,567 & 2,895 & 2,898 \\
\hline Kosovo & No data & No data & No data & No data & No data & No data & 11 & 111 & 114 \\
\hline Lebanon & 2,465 & 3,523 & 1,946 & 2,180 & 3,332 & 1,227 & 3,303 & 3,303 & 2,571 \\
\hline Libya & No data & No data & No data & No data & No data & No data & No data & No data & No data \\
\hline Malta & 14 & 20 & 12 & 12 & 26 & 24 & 23 & 34 & 37 \\
\hline Montenegro & No data & 25,051 & 25,051 & 1,876 & 4,603 & 3,561 & 3,068 & 3,068 & 3,068 \\
\hline Morocco & 1,139 & 4,216 & 3,590 & 3,450 & 3,800 & 17,030 & 17,030 & 16,600 & 8,660 \\
\hline Portugal & 211,501 & 214,242 & 229,717 & 211,071 & 151,460 & 201,054 & 200,151 & 195,974 & 271,532 \\
\hline $\begin{array}{l}\text { Republic of } \\
\text { Macedonia }\end{array}$ & 249 & 509 & 1,333 & 3,380 & 6,213 & 35,164 & 26,431 & 12,589 & 3,146 \\
\hline Serbia & No data & 740 & 830 & 4,494 & 8,661 & 8,635 & 6,237 & 6,340 & 8,228 \\
\hline Slovenia & 23,499 & 26,831 & 29,322 & 29,838 & 29,388 & 30,696 & 30,320 & 33,776 & 38,665 \\
\hline Spain & 622,762 & 736,939 & 804,884 & $1,129,844$ & $1,330,774$ & $1,456,672$ & $1,574,904$ & $1,428,578$ & $1,610,129$ \\
\hline Tunisia & 143,099 & 154,793 & 154,793 & 174,725 & 167,302 & 175,066 & 178,521 & 137,188 & 139,087 \\
\hline Turkey & 93,133 & 100,275 & 124,263 & 109,387 & 325,831 & 383,782 & 320,451 & 343,086 & 474,766 \\
\hline
\end{tabular}


Table 2

Organic Crops Grown in the Mediterranean Basin

\begin{tabular}{|c|c|c|}
\hline Cluster & Country & Main organic products \\
\hline \multirow{9}{*}{ Eastern Adriatic } & & Cereals \\
\hline & Albania & Medicinal herbs, aromatic plants \\
\hline & Bosnia \& Herzegovina & Fresh vegetables \\
\hline & Croatia & Green fodder \\
\hline & Macedonia & Fruits and berries \\
\hline & Montenegro & Grapes \\
\hline & Serbia & Bee pastures \\
\hline & & Wild collection products \\
\hline & & Olives (Albania and Croatia) \\
\hline \multirow{24}{*}{ Mashrec } & Egypt & Cereals \\
\hline & Jordan & Fresh vegetables \\
\hline & Lebanon & Medicinal herbs, aromatic plants \\
\hline & Palestine & Fruits \\
\hline & Syria & Grapes \\
\hline & Turkey & Citrus \\
\hline & & Olives and olive oil \\
\hline & Jordan & Date palm \\
\hline & & Wild collection products \\
\hline & & Animal products (eggs, goat milk, and dairy products) \\
\hline & Lebanon & Essential oils \\
\hline & & Dried fruits \\
\hline & & Processed products \\
\hline & Syria & Cotton \\
\hline & & Dried pulses \\
\hline & & Root crops \\
\hline & & Cotton \\
\hline & & Oilseeds \\
\hline & Turkey & Green fodder \\
\hline & I urkey & Pastures and meadows \\
\hline & & Wild collection products \\
\hline & & Dried fruits \\
\hline & & Animal products (bovine, ovine, poultry, and bees) \\
\hline & & Processed products \\
\hline \multirow{11}{*}{ Maghreb } & & Cereals \\
\hline & & Fresh vegetables \\
\hline & & Medicinal herbs, aromatic plants \\
\hline & Algeria & Green fodder \\
\hline & Libya & Fruits \\
\hline & Morocco & Date palm \\
\hline & Tunisia & Citrus \\
\hline & & Olives \\
\hline & & Grassland \\
\hline & & Wild collection products \\
\hline & & Argan (only in Morocco) \\
\hline
\end{tabular}


One of the most significant obstacles is insufficient number of inputs on the market: seed and pesticides allowed for use in O.F. The next weak point is insufficient and irregular campaign on beneficial effect of organic food on human health. Poor pre-organic farm establishment procedure and the absence of Higher Education Institutions in the knowledge transfer system is another key obstacle for the development of O.F. (Zlatkovski, Mihajlov, \& Mitrev, 2015). Furthermore, the education level and low level of organic farmers' organization are another weak point on the road for local and national development of O.F. IPARD (Instrument for Pre-accession Assistance and Rural Development) funds are unused as well, especially on the measures meant for processors and storage facilities, specialized and certified enterprises for processing and packaging.

Few number of tourist facilities are offering organic menu. Furthermore, underdeveloped sector of rural tourism makes its contribution to the slow development of O.F., too.

The status of the O.F. research outside Macedonia is mainly concentrated in Europe, considered the cradle of organic research (Wilier, 2009). However, in the last few years, studies and experiments on O.F. and practices started emerging in other parts of the world involving several actors. Some of them are the Organic Centre of Canada (OACC), the Brazilian Agriculture Research Corporation (EMBRAPA), and the Rodale Institute in the U.S. Other research activities related to O.F. are mainly carried out by universities. All these initiatives have a common objective which is the collaboration for the promotion and enhancement of organic research worldwide (Reine et al., 2010).

To date the EU contribution to the development of research in organic agriculture has included the funding of around 70 research projects that refer directly (explicit reference in the title) or indirectly (mentioned as part of the topic) to organic agriculture (Zanoli, 2009). The first contribution of EU to organic agriculture research dates back to the FP2 (1987-1993), where in organic agriculture was mentioned as part of the extensification and diversification of agricultural production. At present, only three research projects entirely concern organic agriculture in FP7 (2007-2013), probably due to the overall limited research funding (Zanoli, 2009). Across the Mediterranean, the transfer and dissemination of organic agriculture research results are carried out by means of two main tools: publications and training courses. Internet websites appear to be an important tool for results sharing, diffusion in EU but not in CPC (candidates and potential candidates countries) and SEM (South and East Mediterranean) countries, where more probably farmers and other actors of the agricultural sector still do not have easy access to the computer technology (Reine et al., 2010).

According to the opinions of many researchers, the main research priorities for organic research in the Mediterranean need to be:

- In Macedonia and other CPS country: pest management/plant protection, soil fertility management, agroecology and biodiversity, market study, and promotion;

- In SEM countries: plant protection/biological control, soil fertility management, postharvest and food processing, quality control, and inspection system;

- In EU Mediterranean countries: plant and animal genetic resources, cropping systems, market study and promotion, improving knowledge, and technologies.

\section{Conclusions}

According to the results of the current situations and researches in Macedonia and Mediterranean countries, 
the new opportunities in the near future for development of O.F. especially through applicative scientific research, are in key strengths that are identified by the following real facts and conditions:

- the high qualification of human resources involved in research in organic issues; the existing infrastructures (laboratories and experimental farms) available for research in organic agriculture in Macedonia and Mediterranean countries;

- an adequate transfer of the research results mainly through publications and workshops.

As most influential weaknesses, this paper emphasizes:

- the small number of centers fully specialized in organic research;

- lack of long-term experiment in organic agriculture in Macedonia and Mediterranean countries.

For further work to support organic research in the Mediterranean region, it would be useful to:

- continue monitoring the evolutionary trends of organic research in the Mediterranean in order to base future support initiatives on a comprehensive and updated picture of the situation;

- identify the practical problems of the sector and try to find out how research may contribute to their solution;

- participate in regional Mediterranean and International projects trying to convey and consolidate common interests;

- establish relations and partnership and develop networking at Mediterranean and international level for a better exchange of information and sharing of experience.

\section{References}

Al-Bitar, L, Bteich, M. R., \& Pugliese, P. (2010). Organic agriculture in the Mediterranean region: Updates. In H. Wilier and L. Kilcher (Eds.), The world of organic agriculture. Statistics and emerging 1 rends 2010 (pp. 152-157). Frick: IFOAM and FiBL.

Al-Bitar, L. (2008). Organic agriculture in the Mediterranean: Towards further development. Retrieved from http://ciheam.org/images/CIHEAM/PDFs/Observatoire/NAN/nan30.pdf

Al-Bitar, L., \& Pugliese, P. (2008). The CIHEAM watch letter. Retrieved from http://www.interbio.it/share/img_download/27_ROAM_29_04_2011.pdf

International Centre for Research in Organic Food Systems. (2011). Organic research and development 1996-2010-Effects on industry and society. Retrieved from http://icrofs.dk/fileadmin/icrofs/Nyheder_PDf/Organic_research_and_development_1996-2010.pdf

Ministry of Agriculture, Forestry and Water Economy. (2012). Annual report on agriculture and rural development 2013, Ministry of Agriculture, Forestry and Water Economy, Skopje. Retrieved from http://www.mzsv.gov.mk/organsko_zemjodelsko_proizvodstvo2013.pdf

Ministry of Agriculture, Forestry and Water Economy. (2013). National plan for organic production. MAFWE \& FAO 2013 Skopje. $\quad$ Retrieved from http://www.mzsv.gov.mk/files/National\%20Plan\%20for\%20Organic\%20Production_2013\%20-\%202020.pdf

Organic Trade Association. (2010). U.S. organic industry overview. The Organic Trade Association's 2010 Organic Industry Survey. Retrieved from www.ota.com/pics/documents/2010OrganicIndustrySurveySummary

Organic World. (2015). Global organic farming statistics and news, key indicators and crop data, sources, FIBL database. Retrieved from http://www.organic-world.net/statistics/statistics-data-tables/statistics-data-tables-excel.html? $\mathrm{L}=0$

Reine, B. M., Pugliese, P., \& Al-Bitar, L. (2010). Research in organic agriculture across the Mediterranean Basin. Retrieved from http://www.interbio.it/share/img_download/27_ROAM_29_04_2011.pdf

Sharapatka, B., Urban, J., Cizkova, S., Hejduk, S., Hradil, R., Jursik, J., ... Vanek, D. (2009). Organic agriculture. Ministry of Agriculture of The Chech Republic. Prague: Institute of Agricultural Economics and Information (IAEI).

Wilier, H. (2009). Organic farming research worldwide-An overview. Ecology and Farming, 46, 4-8. 
Zanoli, R. (2009). La ricerca in agricoltura biologica tra spinte europeiste e problematiche natzionali (The research in organic farming between pro-European thrusts and the nationals problems). In M. Crescimanno and G. Schifano (Eds.), Agricoltura biologica: Sistemi produttivi e modelli di cornmerciolizyazione e di consume (Organic farming: Production systems and models of commercialization and of consumption). Palermo: Università degli Studi di Palermo.

Zlatkovski, V., Mihajlov, L., \& Mitrev, S. (2015). Plant protection practice of organic farmers in Macedonia and the role of higher education institution in providing support. British Journal of Applied Science \& Technology, 9(6), 594-599. 